\title{
IGF-1 receptor and IGF binding protein-3 might predict prognosis of patients with resectable pancreatic cancer
}

Toshiki Hirakawaa ${ }^{1}$, Masakazu Yashiro ${ }^{1,2^{*}}$, Akihiro Murata ${ }^{1}$, Keiichiro Hirata ${ }^{1}$, Kenjiro Kimura ${ }^{1}$, Ryosuke Amano ${ }^{1}$, Nobuya Yamada', Bunzo Nakata' ${ }^{1}$ and Kosei Hirakawa ${ }^{1}$

\begin{abstract}
Background: The present study aimed to elucidate the clinicopathologic role of insulin-like growth factor-1 receptor (IGF1R) and IGF binding protein-3 (IGFBP3) in patients with pancreatic cancer. The function of IGFBP3 is controversial, because both inhibition and facilitation of the action of IGF as well as IGF-independent effects have been reported. In this study, IGF1R and IGFBP3 expression was examined, and their potential roles as prognostic markers in patients with pancreatic cancer were evaluated.

Methods: Clinicopathological features of 122 patients with curatively resected pancreatic cancer were retrospectively reviewed, and expression of IGF1R and IGFBP3 was immunohistochemically analyzed.

Results: Expression of IGF1R and IGFBP3 was observed in 50 (41.0\%) and 37 (30.3\%) patients, respectively. IGF1R expression was significantly associated with histological grade $(p=0.037)$. IGFBP3 expression had a significant association with tumor location ( $p=0.023)$, and a significant inverse association with venous invasion $(p=0.037)$. Tumors with IGF1R-positive and IGFBP3-negative expression $(n=32)$ were significantly frequently Stage II and III $(p=0.011)$. The prognosis for IGF1R positive patients was significantly poorer than that for IGF1R negative patients $(p=0.0181$ ). IGFBP3 protein expression did not correlate significantly with patient survival. The subset of patients with both positive IGF1R and negative IGFBP3 had worse overall survival (8.8 months versus 12.6 months, respectively, $p<0.001$ ).
\end{abstract}

Conclusion: IGF1R signaling might be associated with tumor aggressiveness, and IGFBP3 might show antiproliferative effects in pancreatic cancer. Both high IGF1R expression and low IGFBP3 expression represent useful prognostic markers for patients with curatively resected pancreatic cancer.

Keywords: Pancreatic cancer, IGF1R, IGFBP3, Prognosis

\section{Background}

Pancreatic ductal adenocarcinoma (PDAC) is one of the most lethal solid tumors, and carries an extremely poor prognosis [1]. Although the management and treatment of patients with pancreatic cancer have improved over the last few decades, the overall 5-year survival rate remains less than 5\% [2]. Long-term survival is rare, even in patients who undergo a histologically curative

\footnotetext{
* Correspondence: m9312510@med.osaka-cu.ac.jp

'Department of Surgical Oncology, Osaka City University Graduate School of Medicine, 1-4-3 Asahi-machi, Osaka, Abeno-ku, Japan

${ }^{2}$ Oncology Institute of Geriatrics and Medical Science, Osaka City University Graduate School of Medicine, 1-4-3 Asahi-machi, Osaka, Abeno-ku 545-8585, Japan
}

operation, with overall 5-year survival rates ranging from $10 \%$ to $25 \%[3,4]$. The high mortality rate associated with pancreatic cancer is known to be due to extensive invasion into surrounding tissues and metastasis to distant organs at the time of diagnosis (or even after a curative operation); however, the molecular mechanisms of the highly aggressive nature of PDAC remains unclear [5].

Previous studies have shown an association between progression of PDAC and overexpression of several growth factors (and their receptors) including insulinlike growth factor (IGF), vascular endothelial growth factor (VEGF), fibroblast growth factor (FGF), and platelet-derived growth factor (PDGF) [6-8]. Most of 
the cellular effects of IGF-I and IGF-II are mediated by the IGF-I receptor (IGF1R). Binding of the ligand to IGF1R leads to tyrosine phosphorylation of the major receptor substrate followed by activation of certain downstream signaling cascades [9]. The IGFs have been implicated through IGF1R in the pathogenesis, cell proliferation, and cell survival of many cancers [10,11]. IGF-1, which is produced primarily by the liver, is known to play an important role in the regulation of cell proliferation, differentiation, and apoptosis [10-12]. Clinical studies in colorectal, esophageal, and pancreatic cancers have shown that IGF1R signaling correlates with increased tumor growth and malignancy in vitro $[8,13,14]$.

The IGF system is a complex network of growth factors (IGF-I and IGF-II), cell surface trans-membrane receptors (IGF1R), and high affinity IGF-binding proteins (IGFBPs) that play an important role in normal cellular growth and development, and disruption of the balance of this system has been implicated in the etiology and progression of breast and other cancers [15]. Activation of the IGF system stimulates proliferation, differentiation, angiogenesis, metastasis, survival, and resistance to anticancer therapies in many cancers [16], supporting the idea that the IGF system is an attractive therapeutic target. The biological actions of IGFs are modulated by a family of IGFBPs in the local tissue microenvironment $[17,18]$. IGFBP3 is part of the family of six IGFBPs that bind the peptide growth factors IGF-I and IGF-II with high affinity and regulate their bioactivity [19]. IGFBP3 is the most abundant IGFBP, being present in almost all tissues. IGFBP3 inhibits IGF1R mediated signaling by preventing the interaction of IGFs with IGF1R. IGFBP3 regulates the mitogenic action of IGFs or inhibits their antiapoptotic effects through IGFdependent and IGF-independent mechanisms [20,21]. However, there are few evidences of an association between IGFBP3 and enhanced cell proliferation. These findings have encouraged investigators to investigate whether IGFBP3 plays a positive or negative role in IGF-promoted tumor development.

Although serum levels of IGF-I are generally considered to be a positive risk factor for development of colorectal cancer, the role of IGFBP3 appears less clear. Both the inhibition and activation of cellular functions by these proteins have been demonstrated to depend on cell type [22]. The present study examined IGF1R and cell surface-associated IGFBP3 expression in patients with pancreatic cancer.

\section{Methods}

\section{Patients}

A total of 122 patients who had undergone resection of a primary pancreatic tumor at the Department of Surgical Oncology, Osaka City University Hospital were included. The pathologic diagnoses and classifications were made according to the UICC Classification of Malignant Tumors [23]. No patients had hematogenous metastases or peritoneal dissemination before surgery. Histological findings are according to the classification of pancreatic carcinoma in Japan Pancreas Society [24]. Patients' characteristics are shown in Table 1 . The median age of patients was 68 years (range 33-84 years). A total of 79 patients (64.8\%) died during the follow-up period, and the majority of patients were male (67.2\%), and Stage II (78.7\%). The observation period is overall survival time that was set in days as the period from the time of resection until the

Table 1 Patients' clinicopathological characteristics

\begin{tabular}{|c|c|}
\hline Clinicopathologic characteristics & $n=122$ \\
\hline \multicolumn{2}{|l|}{ Gender } \\
\hline Male & 66 \\
\hline Female & 56 \\
\hline \multicolumn{2}{|l|}{ Age (years) } \\
\hline Median & 68 \\
\hline Range & $33-84$ \\
\hline \multicolumn{2}{|l|}{ Tumor location } \\
\hline proximal & 81 \\
\hline distal & 41 \\
\hline \multicolumn{2}{|l|}{ Tumor differentiation } \\
\hline Grade 1 & 35 \\
\hline Grade 2 & 67 \\
\hline Grade 3 & 17 \\
\hline Grade 4 & 3 \\
\hline \multicolumn{2}{|l|}{ Tumor stromal volume } \\
\hline Medullary type (med) & 1 \\
\hline Intermediate type (int) & 85 \\
\hline Scirrhous type (sci) & 36 \\
\hline \multicolumn{2}{|l|}{ T category } \\
\hline $\mathrm{T} 1$ & 11 \\
\hline $\mathrm{T} 2$ & 15 \\
\hline T3 & 84 \\
\hline $\mathrm{T} 4$ & 12 \\
\hline \multicolumn{2}{|l|}{$\mathrm{N}$ category } \\
\hline No & 56 \\
\hline N1 & 66 \\
\hline \multicolumn{2}{|l|}{ Stage } \\
\hline । & 15 \\
\hline$\|$ & 95 \\
\hline III & 12 \\
\hline IV & 0 \\
\hline
\end{tabular}

TNM classification is according to the International Union against Cancer (UICC, 2003).

Medullary type (med): scanty stroma, Intermediate type (int): the quantity of stroma is intermediate between the two above types, Scirrhous type (sci): abundant stroma. 
time of death. The study protocol conformed to the ethical guidelines of the Declaration of Helsinki (1975). This study was approved by the Osaka City University ethics committee. Informed consent was obtained from all patients prior to entry.

\section{Immunohistochemical techniques}

Sections of paraffin-embedded tissue (4- $\mu$ m thick) were prepared. Immunohistochemical staining for IGF1R and IGFBP3 was performed using the avidin-biotin-peroxidase complex method. In brief, the deparaffinized and hydrated tissues were heated for $10 \mathrm{~min}$ at $105^{\circ} \mathrm{C}$ in Target Retrieval Solution (Dako, Carpinteria, CA, USA). Then, the slides were allowed to cool for $20 \mathrm{~min}$ on a lab bench in the Target Retrieval Solution at $25^{\circ} \mathrm{C}$. The slides were incubated overnight at $4^{\circ} \mathrm{C}$ with $5 \mu \mathrm{g} / \mathrm{mL}$ of antihuman IGF1R mouse monoclonal antibody (Abcam, Cambridge, MA, USA) and $5 \mu \mathrm{g} / \mathrm{mL}$ of antihuman IGFBP3 rabbit polyclonal antibody (Abcam, Cambridge, MA, USA).

\section{Immunohistochemical determination}

All slides were examined by two of the authors who were blinded to clinical data. The final evaluation of ambiguous cases was decided after discussion between the two authors. For determination of IGF1Rand IGFBP3 protein immunoreactivity, the cytoplasm and membrane staining intensity and patterns were evaluated according to the following scale. Immunoreactivity for IGF1R was evaluated in the neoplastic epithelial cells using a combined scoring system based on the sum of the staining intensity and the percentage of positive cells. Scores from $0-3$ were given for the staining intensity and the percentage of positive cells as follows: score of 0 , no staining is observed, or is observed in less than $10 \%$ of the tumor cells; score of $1+$, weak staining is detected in $10 \%$ or more of the tumor cells; score of $2+$, moderate staining is observed in $10 \%$ or more of the tumor cells; and score of $3+$, strong staining is observed in $10 \%$ or more of the tumor cells. Scores of 0 and $1+$ were considered to be negative for IGF1R overexpression, while scores of $2+$ and $3+$ were considered to be positive for IGF1R overexpression. Immunoreactivity for IGFBP3 was evaluated in the neoplastic epithelial cells using a combined scoring system based on the sum of the staining intensity and the percentage of positive cells. For determination of IGFBP3 protein immunoreactivity, staining of antibody was considered positive if $>10 \%$ of tumor cells were stained.

\section{Statistical analysis}

The $x^{2}$-test or Fisher's exact test was used to determine the significance of the differences between the covariates. Survival durations were calculated using the Kaplan-Meier method and were analyzed by the log-rank test to compare the cumulative survival durations in the patient groups. The Cox proportional hazards model was used for the univariate and multivariate analyses. All analyses were performed using SPSS software (SPSS Japan, Tokyo, Japan). A $P$-value $<0.05$ was considered to represent statistical significance.

\section{Results}

\section{Expression of IGF1R and IGFBP3}

Tumors with positive IGF1R protein showed cytoplasmic staining. Typical images of positive immunostaining for IGF1R in cancer cells are shown in Figure 1A. Overall, seven cases had a score of 0,69 cases had a score of $1+$,
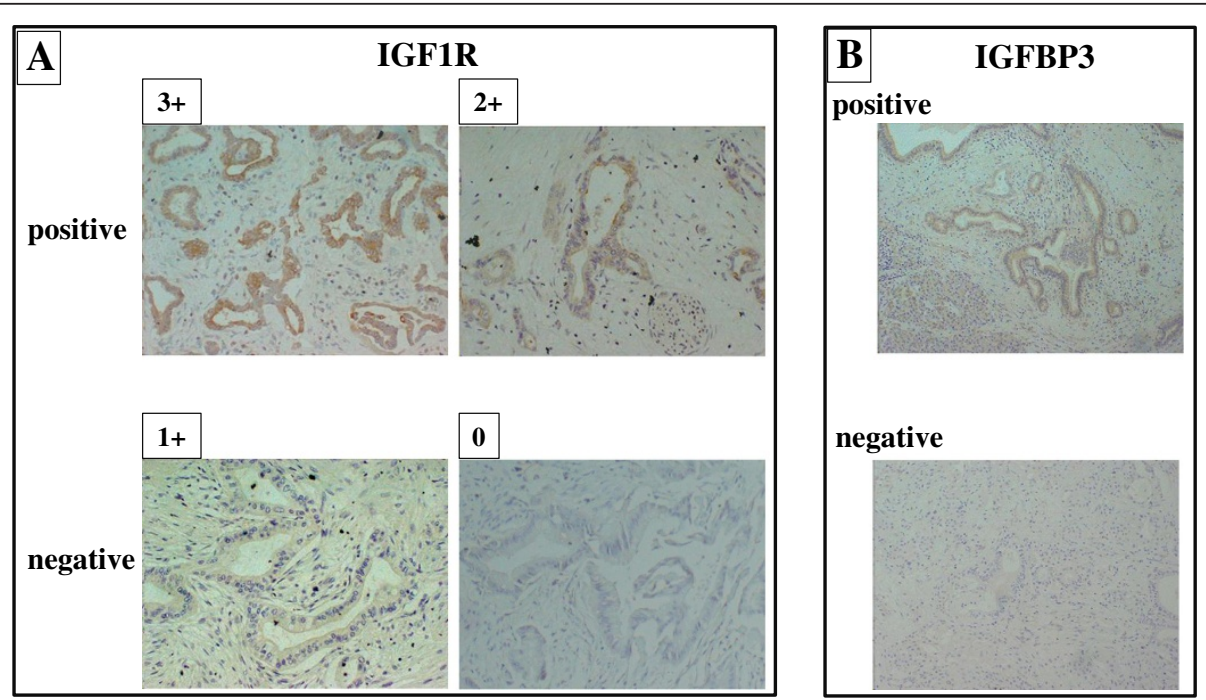

Figure 1 IGF1R and IGFBP3 expression in pancreatic cancer. A, Representative IGF1R staining quantified with scores of 0 to $3+$ according to staining intensity. (Original magnification X 200). IGF1R was mainly expressed in the cytoplasm of pancreatic cancer cells. B, IGFBP3 was expressed in the cell membrane and the cytoplasm of pancreatic cancer cells. 
Table 2 Association between IGF1R \& IFGBP3 expression and clinicopathological factors in resectable pancreatic cancer

\begin{tabular}{|c|c|c|c|c|c|c|c|c|c|}
\hline \multirow{3}{*}{ Characteristics } & \multicolumn{3}{|c|}{ IGF1R expression } & \multicolumn{3}{|c|}{ IGFBP3 expression } & \multicolumn{3}{|c|}{ Both IGF1R (+) and IGFBP3 (-) } \\
\hline & positive & negative & & positive & negative & & positive & others & \\
\hline & $\mathrm{n}=\mathbf{5 0}$ & $n=72$ & $p$-value & $\mathrm{n}=\mathbf{3 7}$ & $\mathrm{n}=85$ & $p$-value & $\mathrm{n}=32$ & $n=90$ & $p$-value \\
\hline \multicolumn{10}{|l|}{ Age } \\
\hline$<60$ & 7 & 18 & & 10 & 15 & & 3 & 22 & \\
\hline$\geqq 60$ & 43 & 54 & 0.139 & 27 & 70 & 0.238 & 29 & 68 & 0.07 \\
\hline \multicolumn{10}{|l|}{ Gender } \\
\hline Male & 25 & 31 & & 15 & 41 & & 16 & 40 & \\
\hline Female & 25 & 41 & 0.449 & 22 & 44 & 0.433 & 16 & 50 & 0.588 \\
\hline
\end{tabular}

T category

$\begin{array}{lcccccccc}\mathrm{T} 1, \mathrm{~T} 2 & 9 & 17 & & 7 & 19 & 3 & 23 \\ \mathrm{~T} 3, \mathrm{~T} 4 & 41 & 55 & 0.457 & 30 & 66 & 0.670 & 29 & 67\end{array}$

N category

$$
\text { NO }
$$

N1

Stage

।

Tumor location

$$
\text { proximal }
$$

distal

Tumor differentiation

$$
\text { Grade1, } 2
$$

Grade 3, 4

Lymphatic invasion

$$
\begin{aligned}
& \text { negative } \\
& \text { positive }
\end{aligned}
$$

Arterial invasion

$$
\begin{aligned}
& \text { negative } \\
& \text { positive }
\end{aligned}
$$

Venous invasion

$$
\begin{aligned}
& \text { negative } \\
& \text { positive }
\end{aligned}
$$

\begin{tabular}{|c|c|c|c|}
\hline 4 & 11 & 5 & 10 \\
\hline 46 & 61 & 32 & 75 \\
\hline
\end{tabular}

$23 \quad 33$

27

33

$\begin{array}{ll} & 20 \\ 0.986 & 17\end{array}$

36
49

$\begin{array}{lll}14 & 42 \\ 0.233 & 18 & 48\end{array}$

0.077

30

51

0.787

$\begin{array}{ll}0 & 15 \\ 32 & 75\end{array}$

$31 \quad 50$

$19 \quad 22$

0.392

$\begin{array}{ll}7 & 34\end{array}$

(2.787

0.023

68
17

0.082

$\begin{array}{ll}18 & 63 \\ 14 & 27\end{array}$

$\begin{array}{cccc}46 & 56 & & 34 \\ 4 & 16 & 0.037 & 3\end{array}$

17

0.082

$\begin{array}{ll}28 & 74 \\ 4 & 16\end{array}$

$\begin{array}{lll}24 & 42 & 19 \\ 26 & 30 & 0.260\end{array}$

47
38

$\begin{array}{lll} & 15 & 51 \\ 0.688 & 17 & 39\end{array}$

30

\begin{tabular}{|c|c|c|c|c|c|c|c|c|c|}
\hline med \& int & 31 & 55 & & 27 & 59 & & 19 & 67 & \\
\hline sci & 19 & 17 & 0.087 & 10 & 26 & 0.692 & 13 & 23 & 0.108 \\
\hline
\end{tabular}

$\begin{array}{ll}43 & 67 \\ 7 & 5\end{array}$

$\begin{array}{cc}33 \\ 0.198 & 4\end{array}$

77
8

$\begin{array}{ccc} & 27 & 83 \\ 0.754 & 5 & 7\end{array}$

Intrapancreatic nerve invasion

$\begin{array}{lllll}\text { negative } & 21 & 38 & & 16 \\ \text { positive } & 29 & 34 & 0.241 & 21 \\ \text { nor stromal volume } & & & & \end{array}$

Tumor stromal volume

IGFBP3 expression

$\begin{array}{lll}\text { negative } & 32 & 53 \\ \text { positive } & 18 & 19\end{array}$

$19 \quad 0.256$

Medullary type (med): scanty stroma, Intermediate type (int): the quantity of stroma is intermediate between the two above types, Scirrhous type (sci): abundant stroma. 
23 cases had a score of $2+$, and 27 cases had a score of $3+$. Thus, 50 cases (41\%) were positive for IGF1R overexpression. Most of the positive staining was observed in the cytoplasm, while two cases showed positive staining in both membranes and cytoplasm. In contrast, no or weak staining was seen in the cytoplasm of pancreatic duct cells and acinar cells, and there was no staining in the membranes. Figure $1 \mathrm{~B}$ shows a representative picture of IGFBP3 staining. IGFBP3 was mainly expressed in the cytoplasm of cancer cells. Eighty-five cases of PDAC showed negative IGFBP3 expression, whereas 37 cases were positive.

\section{Clinicopathological association of IGF1R and IGFBP3 expression}

Table 2 shows the association of clinicopathological characteristics and IGF1R or/and IGFBP3 expression. IGF1R expression had a significant association with histological grade (Fisher's exact test, $p=0.037$ ). Stromal volume tended to be more abundant in PDAC with IGF1R overexpression, but no significant difference was observed ( $\chi^{2}$ test, $\left.p=0.087\right)$. IGFBP3 expression had a significant association with tumor location $\left(\chi^{2}\right.$ test, $p=0.023)$, and a significant inverse association with venous invasion (Fisher's exact test, $p=0.037$ ). IGFBP3 expression tended to be frequent in differentiated PDAC in histological grade, but no significant difference was observed ( $\chi^{2}$ test, $\left.p=0.082\right)$.

\section{Relationship between clinicopathological features and tumors with IGF1R-positive and IGFBP3-negative expression}

Among the 50 patients with positive IGF1R expression, 32 patients (64.0\%) had negative IGFBP3 expression. Tumors with IGF1R-positive and IGFBP3-negative expression $(n=32)$ were significantly frequently found to have Stage II and III cancer ( $\chi^{2}$ test, $p=0.011$ ) compared to the other groups $(n=90)$. Tumors with IGF1R-positive and IGFBP3-negative expression tended to be in older patients (Fisher's exact test, $p=0.07$ ) and advanced T stage $\left(x^{2}\right.$ test, 0.077). Among the 72 patients with negative IGF1R, 53 patients (73.6\%) showed negative IGFBP3 expression, whereas 19 patients (26.4\%) had positive IGFBP3 expression. No association was found between IGF1R and IGFBP3 expression.
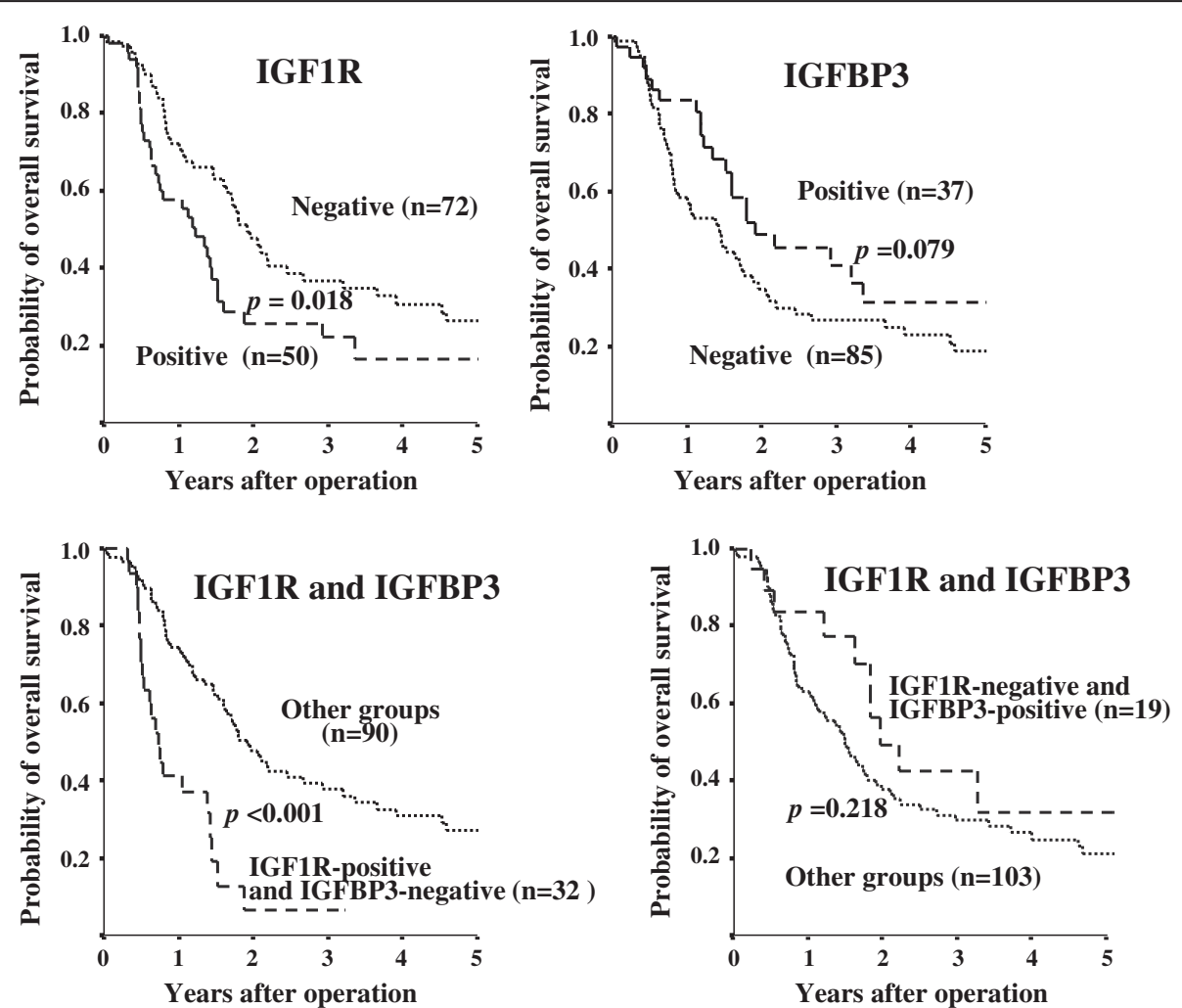

Figure 2 Overall survival of patients based on IGF1R and IGFBP3 expression. The survival curve shows the Kaplan-Meier overall survival curves in relation to the IGF1R and IGFBP3 levels in patients with pancreatic cancer. A statistically significant difference in survival was observed between patients with IGF1R-positive and IGF1R-negative tumors ( $p=0.018$ ). The prognosis of patients with IGF1R-positive and IGFBP3-negative patients showed a significant correlation with overall survival $(p<0.001)$. IGFBP3 expression alone tended to be associated with overall survival $(p=0.079)$. The co-expression of IGF1R-negative and IGFBP3-positive PDAC was not associated with overall survival $(p=0.218)$. 


\section{Survival}

Kaplan-Meier survival analyses showed a significantly poorer overall survival in the IGF1R-positive group compared to the IGF1R-negative group $(\mathrm{p}=0.018)$. Moreover, the prognosis of patients with IGF1R-positive and IGFBP3-negative PDAC was significantly poorer than that of other patients $(p<0.001)$. In contrast, the prognosis of patients with IGF1R-negative and IGFBP3positive PDAC was not significantly correlation with overall survival $(p=0.218)$, while IGFBP3 expression alone tended to be associated with overall survival $(\mathrm{p}=0.079)$ (Figure 2). Figure 3 shows the overall survival stratified for IGF1R and IGFBP3 expression in cancer cells according to clinical stage II status. The prognosis for IGF1R positive patients with stage II tumors was significantly $(p=0.0080)$ poorer than that for IGF1R negative patients, while no significant difference in the prognosis was found between the IGF1R expression in either stage I or III tumors (data not shown). On univariate analysis, three factors, IGF1R overexpression, IGF1R-positive and IGFBP3negative expression, and lymph node metastasis, were significantly associated with worse overall survival. Because IGF1R status is deeply associated with IGF1R and IGFBP3 status, multivariate analysis was performed with two factors: IGF1R-positive and IGFBP3-negative expression, and lymph node metastasis. The multivariate survival analysis indicated that IGF1R-positive and IGFBP3-negative expression, along with lymph node metastasis, were independent prognostic indicators (Table 3). IGF1R-positive and IGFBP3-negative expression and lymph node metastasis were independent predictors of poor prognosis.

\section{Discussion}

The present study analyzed the immunohistochemical expression of IGF1R and IGFBP3 with clinicopathological variables and the correlation with overall survival in 122 patients with PDAC. IGF1R expression had a significant association with histological grade of tumor differentiation, and also tended to be associated with abundant stroma. These findings suggest that the IGF1R signaling system might be correlated with histopathologic features of PDAC. It has been reported that IGF1 is produced from stromal cells [11]. There might be an interaction between cancer cells and stromal cells via IGF/IGF1R signaling. PDAC patients with IGF1R-positive expression showed significantly poorer survival, compared to the IGF1Rnegative group (Figure 2). The present findings suggest
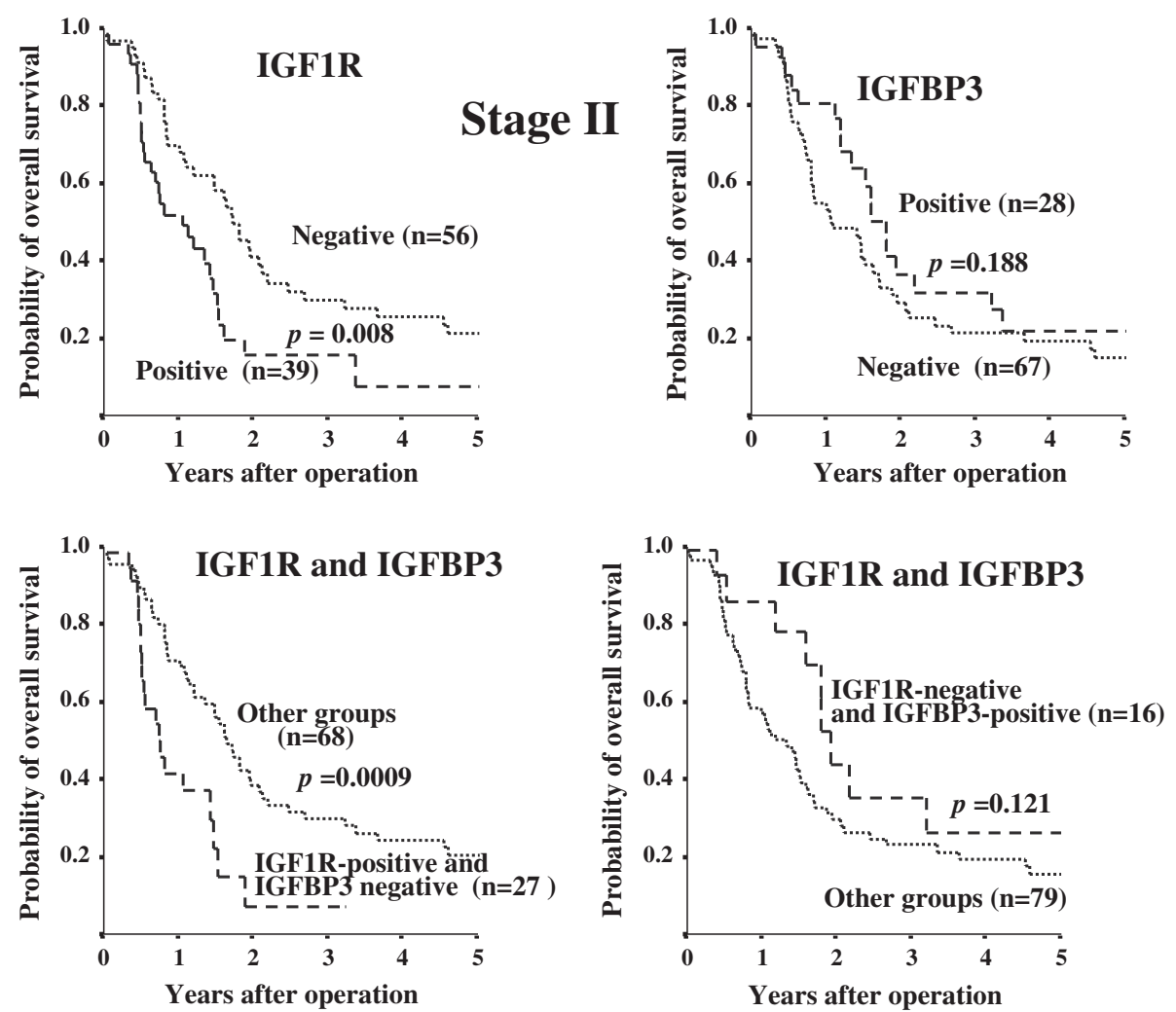

Figure 3 Overall survival stratified by IGF1R and IGFBP3 expression in cancer cells in patients with clinical stage II tumors. Prognosis of IGF1R-positive cancer was significantly poorer $(p=0.008)$ than that of IGF1R-negative cancer in the stage II group. Analysis of prognosis of patients with IGF1R-positive and IGFBP3-negative tumors shows a significant correlation with overall survival $(p=0.0009)$ in patients with stage II tumors. 
Table 3 Univariate and multivariate survival analyses in pancreatic cancer

\begin{tabular}{|c|c|c|c|c|c|c|}
\hline \multirow[t]{2}{*}{ Variable } & \multicolumn{3}{|c|}{ Univariate analysis } & \multicolumn{3}{|c|}{ Multivariate analysis } \\
\hline & Hazard ratio & $95 \% \mathrm{Cl}$ & $p$-value & Hazard ratio & $95 \% \mathrm{Cl}$ & $p$-value \\
\hline \multicolumn{7}{|l|}{ IGF1R expression } \\
\hline Positive vs negative & 1.714 & $1.091-2.693$ & 0.020 & & & \\
\hline \multicolumn{7}{|l|}{ IGFBP3 low expression } \\
\hline Positive vs negative & 1.561 & $0.946-2.576$ & 0.081 & & & \\
\hline \multicolumn{7}{|l|}{ IGF1R (+) \& IGFBP3 (-) } \\
\hline Positive vs negative & 3.101 & $1.843-5.218$ & $<0.001$ & 3.060 & $1.823-5.138$ & $<0.001$ \\
\hline \multicolumn{7}{|l|}{ Gender } \\
\hline male vs female & 0.975 & $0.623-1.525$ & 0.911 & & & \\
\hline \multicolumn{7}{|l|}{ Age } \\
\hline$\geqq 60$ vs $<60$ & 1.444 & $0.822-2.537$ & 0.201 & & & \\
\hline \multicolumn{7}{|l|}{$T$ category } \\
\hline 3,4 vs 1,2 & 1.844 & $0.997-3.413$ & 0.051 & & & \\
\hline \multicolumn{7}{|l|}{ Lymph node metastasis } \\
\hline Positive vs negative & 1.79 & $1.106-2.736$ & 0.017 & 1.718 & $1.092-2.702$ & 0.019 \\
\hline \multicolumn{7}{|l|}{ Tumor location } \\
\hline proximal vs distal & 1.108 & $0.671-1.736$ & 0.752 & & & \\
\hline \multicolumn{7}{|l|}{ Lymphatic invasion } \\
\hline Positive vs negative & 1.332 & $0.855-2.075$ & 0.205 & & & \\
\hline \multicolumn{7}{|l|}{ Arterial invasion } \\
\hline Positive vs negative & 1.209 & $0.554-2.637$ & 0.634 & & & \\
\hline \multicolumn{7}{|l|}{ Venous invasion } \\
\hline Positive vs negative & 1.579 & $0.812-3.071$ & 0.178 & & & \\
\hline \multicolumn{7}{|l|}{ Intrapancreatic nerve invasion } \\
\hline Positive vs negative & 1.452 & $0.930-2.267$ & 0.101 & & & \\
\hline \multicolumn{7}{|l|}{ Tumor differentiation } \\
\hline grade 1,2 vs grade 3,4 & 1.452 & $0.826-2.551$ & 0.195 & & & \\
\hline \multicolumn{7}{|l|}{ Tumor stromal volume } \\
\hline med/int vs scir & 0.724 & $0.453-1.156$ & 0.176 & & & \\
\hline
\end{tabular}

that the IGF1R signaling system might be correlated with tumor aggressiveness in PDAC, as has been previously reported $[25,26]$.

IGF bioavailability is regulated by a family of six IGFbinding proteins (IGFBP), of which IGFBP3 is the major IGF carrier protein [17]. The function of IGFBP3 is controversial. IGFBP3 has been shown to produce either inhibition [27-29] or potentiation [30-32] of IGF effects. The direction of the effect may depend on the cell type [27]. In this study, favorable survival in the IGFBP3-positive group was noted, but statistical significance was not obtained (Figure 2). IGFBP3 expression had an inverse association with venous invasion. These findings suggest that IGFBP3 might show antiproliferative effects in PDAC. IGFBP3 expression had a significant association with proximal tumors. Most insulin is secreted from the distal pancreas.
IGFBP3 expression might be associated with lesions involving insulin secretion.

Next, the significance of the combination of IGF1R expression and IGFBP3 expression was evaluated. Tumors with IGF1R-positive and IGFBP3-negative expression were significantly frequently found at an advanced clinical stage (II or III), compared to the other groups. The prognosis of patients with IGF1R-positive and IGFBP3-negative PDAC was poorer than that of other groups, especially in patients with stage II tumors (Figure 3). The IGF1R-positive and IGFBP3-negative subgroup was the group with the worst prognosis (Figures $2 \& 3$ ). These findings suggest that IGFBP3 could produce inhibition of IGF effects. Decreased IGFBP3 production and increased IGF1R expression in pancreas tumors might enhance the tumorigenesis and cell motility as previously reported [26,33,34]. 
Prediction of prognosis in patients with operable PDAC is important to determine the adjuvant therapy. This is especially true in patients with stage II tumors, because the local recurrence rate of PDAC is high, even in patients with curative R0 operations. The present study suggests that combined evaluation of IGF1R expression and IGFBP3 expression is a useful prognostic factor in pancreatic cancer, especially with clinical stage II tumors.

Although IGFBP3 is the major IGF carrier protein, some paper reported that IGFBP3 has IGF-independent antiproliferative and proapoptotic effects $[20,21]$. The inhibition of IGF1-induced functions by cell surfaceassociated IGFBP3 have been reported [27,29]; however, the relationship between membrane-associated IGFBPs and IGF1R signaling is less well understood. Therefor significance of co-expression of IGFBP3 and IGF1R in PDAC remains obscure. We then analyzed the significance of IGF1R-negative and IGFBP3-positive group with respect to overall survival (in the right bottom diagram of Figures $2 \& 3$ ), which might clarify whether IGFBP3 is IGF1/IGF1R signaling-independent or not. Although IGFBP3 expression alone tended to be associated with overall survival $(\mathrm{p}=0.079)$, co-expression of IGF1R-negative and IGFBP3-positive PDAC was not associated with overall survival $(p=0.218)$. These data suggested that the function of IGFBP3 might be dependent on IGF1R expression.

\section{Conclusion}

IGF1R signaling might be associated with tumor aggressiveness, and IGFBP3 might show antiproliferative effects in pancreatic cancer. Both high IGF1R expression and low IGFBP3 expression represent useful prognostic markers for patients with curatively resected pancreatic cancer.

\section{Competing interests}

All of the authors have no conflicts of interest to disclose.

\section{Authors' contributions}

$\mathrm{TH}$ : study design, data analysis, material sampling, paper preparation. MY: study design, data analysis, interpretation of data, paper preparation. $\mathrm{AM}, \mathrm{KH}$, $\mathrm{KK}, \mathrm{RA}, \mathrm{NY}$ and BN: material sampling. $\mathrm{KH}$ : data analysis, interpretation. All authors read and approved the final manuscript.

\section{Sources of support}

This study was supported in part, by the National Cancer Center Research and Development Fund (23-A-9), and by Grants-in Aid for Scientific Research (KAKENHI, Nos. 20591573, 22390262, and 23390329) from the Ministry of Education, Science, Sports, Culture and Technology of Japan.

Received: 14 March 2013 Accepted: 15 August 2013

Published: 21 August 2013

\section{References}

1. Jemal A, Siegel R, Xu J, Ward E: Cancer statistics, 2010. CA Cancer J Clin 2010, 60(5):277-300.

2. Cho K, Ishiwata T, Uchida E, Nakazawa N, Korc M, Naito Z, Tajiri T: Enhanced expression of keratinocyte growth factor and its receptor correlates with venous invasion in pancreatic cancer. Am J Pathol 2007, 170(6):1964-1974.
3. Cleary SP, Gryfe R, Guindi M, Greig P, Smith L, Mackenzie R, Strasberg S, Hanna S, Taylor B, Langer B, et al: Prognostic factors in resected pancreatic adenocarcinoma: analysis of actual 5-year survivors. J Am Coll Surg 2004, 198(5):722-731.

4. Sohn TA, Yeo CJ, Cameron JL, Koniaris L, Kaushal S, Abrams RA, Sauter PK, Coleman J, Hruban RH, Lillemoe KD: Resected adenocarcinoma of the pancreas- 616 patients: results, outcomes, and prognostic indicators. J Gastrointest Surg 2000, 4(6):567-579.

5. Spannuth WA, Nick AM, Jennings NB, Armaiz-Pena GN, Mangala LS, Danes CG, Lin YG, Merritt WM, Thaker PH, Kamat AA, et al: Functional significance of VEGFR-2 on ovarian cancer cells. Int J Cancer 2009, 124(5):1045-1053.

6. Doi Y, Yashiro M, Yamada N, Amano R, Noda S, Hirakawa K: VEGF-A/VEGFR2 signaling plays an important role for the motility of pancreas cancer cells. Ann Surg Oncol 2012, 19(8):2733-2743.

7. Ozawa F, Friess H, Tempia-Caliera A, Kleeff J, Buchler MW: Growth factors and their receptors in pancreatic cancer. Teratog Carcinog Mutagen 2001, 21(1):27-44.

8. Bergmann U, Funatomi H, Yokoyama M, Beger HG, Korc M: Insulin-like growth factor I overexpression in human pancreatic cancer: evidence for autocrine and paracrine roles. Cancer Res 1995, 55(10):2007-2011.

9. LeRoith D, Werner H, Beitner-Johnson D, Roberts CT Jr: Molecular and cellular aspects of the insulin-like growth factor I receptor. Endocr Rev 1995, 16(2):143-163.

10. Furstenberger G, Senn HJ: Insulin-like growth factors and cancer. Lancet Oncol 2002, 3(5):298-302.

11. Pollak MN, Schernhammer ES, Hankinson SE: Insulin-like growth factors and neoplasia. Nat Rev Cancer 2004, 4(7):505-518.

12. Pollak M: Insulin-like growth factor physiology and cancer risk. Eur $J$ Cancer 2000, 36(10):1224-1228.

13. Lahm H, Suardet L, Laurent PL, Fischer JR, Ceyhan A, Givel JC, Odartchenko $\mathrm{N}$ : Growth regulation and co-stimulation of human colorectal cancer cell lines by insulin-like growth factor I, II and transforming growth factor alpha. Br J Cancer 1992, 65(3):341-346.

14. Chen SC, Chou CK, Wong FH, Chang CM, Hu CP: Overexpression of epidermal growth factor and insulin-like growth factor-I receptors and autocrine stimulation in human esophageal carcinoma cells. Cancer Res 1991, 51(7):1898-1903.

15. Renehan AG, Zwahlen M, Minder C, O'Dwyer ST, Shalet SM, Egger M: Insulin-like growth factor (IGF)-I, IGF binding protein-3, and cancer risk: systematic review and meta-regression analysis. Lancet 2004, 363 (9418):1346-1353.

16. Samani AA, Yakar S, LeRoith D, Brodt P: The role of the IGF system in cancer growth and metastasis: overview and recent insights. Endocr Rev 2007, 28(1):20-47.

17. Butt AJ, Fraley KA, Firth SM, Baxter RC: IGF-binding protein-3-induced growth inhibition and apoptosis do not require cell surface binding and nuclear translocation in human breast cancer cells. Endocrinology 2002, 143(7):2693-2699.

18. Hwa V, Oh Y, Rosenfeld RG: Insulin-like growth factor binding proteins: a proposed superfamily. Acta Paediatr Supp/ 1999, 88(428):37-45.

19. Firth SM, Baxter RC: Cellular actions of the insulin-like growth factor binding proteins. Endocr Rev 2002, 23(6):824-854.

20. Baxter RC: Insulin-like growth factor (IGF)-binding proteins: interactions with IGFs and intrinsic bioactivities. Am J Physiol Endocrinol Metab 2000, 278(6):E967-976.

21. Baxter RC: Signalling pathways involved in antiproliferative effects of IGFBP-3: a review. Mol Pathol 2001, 54(3):145-148.

22. Kelley KM, Oh Y, Gargosky SE, Gucev Z, Matsumoto T, Hwa V, Ng L, Simpson DM, Rosenfeld RG: Insulin-like growth factor-binding proteins (IGFBPs) and their regulatory dynamics. Int J Biochem Cell Biol 1996, 28(6):619-637.

23. Sobin LH: TNM, sixth edition: new developments in general concepts and rules. Semin Surg Oncol 2003, 21(1):19-22.

24. Isaji S, Kawarada Y, Uemoto S: Classification of pancreatic cancer: comparison of Japanese and UICC classifications. Pancreas 2004, 28(3):231-234

25. Liu JP, Baker J, Perkins AS, Robertson EJ, Efstratiadis A: Mice carrying null mutations of the genes encoding insulin-like growth factor I (Igf-1) and type 1 IGF receptor (Igf1r). Cell 1993, 75(1):59-72.

26. Baserga $R$, Hongo A, Rubini M, Prisco M, Valentinis B: The IGF-I receptor in cell growth, transformation and apoptosis. Biochim Biophys Acta 1997, 1332(3):F105-126. 
27. Rogers J, Wiltrout L, Nanu L, Fant ME: Developmentally regulated expression of IGF binding protein-3 (IGFBP-3) in human placental fibroblasts: effect of exogenous IGFBP-3 on IGF-1 action. Regul Pept 1996, 61(3):189-195.

28. Oh Y, Muller HL, Lamson G, Rosenfeld RG: Insulin-like growth factor (IGF)independent action of IGF-binding protein-3 in Hs578T human breast cancer cells. Cell surface binding and growth inhibition.J Biol Chem 1993, 268(20):14964-14971.

29. Samaras SE, Hammond JM: Insulin-like growth factor binding protein-3 inhibits porcine granulosa cell function in vitro. Am J Physiol 1995, 268(6 Pt 1):E1057-1064.

30. Chevalier $X$, Tyler JA: Production of binding proteins and role of the insulin-like growth factor I binding protein 3 in human articular cartilage explants. Brit J Rheumatol 1996, 35(6):515-522.

31. Conover CA, Clarkson JT, Bale LK: Factors regulating insulin-like growth factor-binding protein-3 binding, processing, and potentiation of insulinlike growth factor action. Endocrinology 1996, 137(6):2286-2292.

32. Chen JC, Shao ZM, Sheikh MS, Hussain A, LeRoith D, Roberts CT Jr, Fontana JA: Insulin-like growth factor-binding protein enhancement of insulinlike growth factor-I (IGF-I)-mediated DNA synthesis and IGF-I binding in a human breast carcinoma cell line. J Cell Physiol 1994, 158(1):69-78.

33. Baker J, Liu JP, Robertson EJ, Efstratiadis A: Role of insulin-like growth factors in embryonic and postnatal growth. Cell 1993, 75(1):73-82.

34. Mauro L, Salerno M, Morelli C, Boterberg T, Bracke ME, Surmacz E: Role of the IGF-I receptor in the regulation of cell-cell adhesion: implications in cancer development and progression. J Cell Physiol 2003, 194(2):108-116.

doi:10.1186/1471-2407-13-392

Cite this article as: Hirakawa et al:: IGF-1 receptor and IGF binding protein-3 might predict prognosis of patients with resectable pancreatic cancer. BMC Cancer 2013 13:392.

\section{Submit your next manuscript to BioMed Central and take full advantage of:}

- Convenient online submission

- Thorough peer review

- No space constraints or color figure charges

- Immediate publication on acceptance

- Inclusion in PubMed, CAS, Scopus and Google Scholar

- Research which is freely available for redistribution 